\title{
A conceptual review of capital structure under risk-based capital regime, risk profile of insurer's and performance
}

\author{
Sarfaraz Ahmed Bhutto ${ }^{1 *}$, Ikhtiar Ali Ghumro ${ }^{1}$, Zulfiqar Ali Rajper ${ }^{2}$, Saifullah \\ Shaikh ${ }^{1}$
}

\begin{abstract}
This paper evaluates capital structure under risk-based capital regime from the perspective of insurance firms and its performance. It also evaluates the moderating effect of insurer's risk profile on capital-performance relationship. The authors aim to reveal ambiguities, gaps and omissions in the literature and to sketch avenues for future research. A conceptual framework for capital structure under risk-based capital era and its application is suggested focusing on equity, technical provision and required risk propensity for maximizing profit and wealth for all stakeholders. The research reviews that capital structure of insurers differs from non-insurance firms as such risk-based capital regulation must not only focus on the various types of risk but also recognized these differences. It is shown that insurers' capital structure contains equity and technical provisions which comprises accruals and creditors, payable claims and insurance funds as an alternative of equity and financial debt as it is with conventional non-insurance firms. This study thus stressed that for capital structure to best explain performance of insurers, it must be measured by equity ratio and technical provision ratio in place of debt ratio and corporate risk profile (quantitative and qualitative) must enter its sequence of performance relational analysis and effectiveness equations. We stressed further that only with the proposed conceptual framework would a holistic understanding of insurer's capital structure be achieved while the observed contradictory and inconclusive empirical findings on capital structure and firm performance could be resolved.
\end{abstract}

Keywords: Risk-based capital, capital structure, financing decision, insurer risk profile, insurer's performance

JEL Code: M54, J19

\section{Introduction}

The mandatory requirement for firms to hold higher capital is essentially an exercise of regulatory oversight function and power to ensure that firms are adequately capitalized to remain solvent and liquid overtime and in line with the volume of risk assumed. According to Cheng \& Weiss (2013) under RBC, capital structure is tinkered by finding the 'best possible' and less costly source of fund to shore up capital base and

\footnotetext{
${ }^{1}$ Institute of commerce, Faculty of Management Sciences, Shah Abdul Latif University Khairpur, Sindh, Pakistan

${ }^{2}$ Department of Commerce, The Shaikh Ayaz University Shikarpur, Sindh, Pakistan. Corresponding Author, sarfaraz_ahmed0333@yahoo.com
} 
Sarfaraz Ahmed Bhutto et al. A conceptual review of capital structure under risk-based capital regime, risk profile of insurer's and performance (pp. 15-27)

make the firm able to fulfill any liability or obligations that may arise or fall due in the course of business operation. Therefore, discussions under RBC should focus on capital structure because it is the primary target of the regulation. Capital structure is defined as funding options available for firm to finance its operations. Moreover, it is measured as the basis for company's survival and has been deliberately and extensively studied in the literature of corporate finance (Dhaene et al., 2015). Such measures as leverage ratio, short-, long-, and total debt to total asset are often used to represent capital structure whereas theories describe capital structure as basically consisting of equity and debt. Under RBC, firms could raise funds either from equity or debt or both sources. However, insurer's capital structure differs; instead, it is made of technical provisions and equity (Florio \& Leoni, 2017). This description extends capital structure equation of insurance firms beyond equity and debt to creditors and accruals and unpaid claims of policyholders. This will require a different proxy for capital structure in insurance studies.

Briefly, ownership is considered as equity contribution whereas technical provision is the mixture of debt (insurance funds) and liabilities which have non-interest bearings (accruals and creditors and unpaid claims of policyholders) all of which constitute insurance obligations. This conceptualization of insurance capital structure has important implications such as the opportunity cost of the non-interest-bearing liabilities like loss of business, premium and profit and loss of credit-worthiness, more fund and high cost of capital. These constitute the current debatable issues among scholars in finance, risk management and insurance, as insurance firms are virtually all the time left out in discussions on capital structure thus resulting not only on scarce, but incomplete literature (Dhaene et al., 2015). Theories of capital structure relevance predict positive effect of a firm's capital structure performance. However, the use of the above conventional proxies may not adequately explain insurer's capital structure as the non-interest-bearing liabilities which opportunity costs plays significant role in insurer's cost of capital are excluded. Also, the above proxies reflect debt structure instead of capital structure, in which case, capital structure is inappropriately represented by one dimension (e.g. debt-equity ratio) or one attribute (e.g. debt) which has been criticized as being inappropriate or incomplete measure that can lead to vague information and conclusion about firm's capital-performance relationship (Shubita \& Alsawalhah, 2012).

From inception in insurance sector, the focus of $\mathrm{RBC}$ has been more on the types of risks covered and correct formulae for its determination rather than on studying the immediate effect on capital structure and how that has translated to better performance (Yusof, Lau, \& Osman, 2015). This oversight has led to miss-conceptualization with subtle potential consequences one of which is a decision dilemma to practitioners and policy makers as some authors have blamed the government and regulators for the inadequacies of the policy (Muhlnickel, Weiss, \& Schmidt, 2016; Mutenga \& Staikouras, 2007; and, Aghoghobvia, 2005). Also, RBC regime aimed to change firm behaviors including their attitude toward risk taking (Hartman, Braithwaite, Butsic et al., 1992). This implies that studying the direct effect of capital structure on Sukkur IBA Journal of Management and Business - SIJMB | Vol 8 No. 1 January - June 2021 
Sarfaraz Ahmed Bhutto et al. A conceptual review of capital structure under risk-based capital regime, risk profile of insurer's and performance

performance may not provide sufficient information on such relationship as past outcome may still not change from being mixed, inconclusive and inconsistent (Gaganis \& Pasiouras, 2013).

The above discussion shows that capital-performance relation goes beyond one attribute or dimension measure and from direct to interaction, effect and ultimately from a narrow to a holistic evaluation. Therefore, a right framework for analysis is imperative. Based on the suggestion of an inclusive investigation involving insurance capital, its regulation and performance (Dhaene et al., 2015), these researchers argued that the ambiguities in past research outcomes may not be unrelated to lack of right framework to conduct such inclusive investigation. Therefore, the conceptual research questions are: what effect would capital structure measured by equity ratio and technical provision ratio have on insurer's performance under RBC? And, what is the moderation effect of insurer's risk profile on issuer's capital- performance relationship under RBC? To analyze these questions from a conceptual perspective, this paper firstly examines theoretical background of capital structure and firm performance and then provides some evidence of capital structure interaction with risk profile under RBC regime. Finally, a conceptual framework is suggested which may provide a holistic and better understanding of capital structure and its interaction with CRP in relation to firm performance from insurance perspective.

\section{The Theoretical Background}

RBC regime focuses on capital regulation. It is a domain in Finance, Insurance and Risk Management that has suffered dearth of research interest in insurance studies (Dhaene et al., 2015). In particular, some theories and few studies have implicitly highlighted the link between RBC and capital structure and its integration with risk in influencing performance (Hoyt \& Liebenberg, 2011; Baxter et al., 2013; Vatavu, 2015; Hamidah, 2016). In the section that follows, these theories and their empirical application are discussed.

\subsection{Dynamic tradeoff theory and empirical application}

The challenge in analyzing insurance capital structure lies on knowing what to tradeoff as insurance capital structure is complex. As an extension of the tradeoff theory, a central claim of the dynamic tradeoff theory is that firms intend to choose the debt level by equating the costs of financial suffering and tax shield of advantage. According to Burkhanova, Enkov, Korotchenko, et. al., (2012) the theory undertakes "...that high capital adjustment cost at persistent level may vary capital structure of firm". This illustrates how capital structure reacts to RBC in anticipation of better performance. Simply, the theory foresees that "at a high debt ratio, firms may avoid bankruptcy cost by adjusting the optimal debt level" (Matemilola, Ariffin \& McGowan Jr., 2012, p. 133). By tradeoff theory, insurers have more to tradeoff to balance equity and technical provision than non-insurers do with equity and debt. Table 1 present areas of tradeoff for insurers comparatively with noninsurers. The various areas highlighted in Table 1 constitute issues of concern for insurers in using equity. Technical requirements on the 
Sarfaraz Ahmed Bhutto et al. A conceptual review of capital structure under risk-based capital regime, risk profile of insurer's and performance

other side, are fundamentally assessed amounts and are thus enclosed by high uncertainty", because it is the most essential source of asymmetric information relevant to external financing (Dhaene et al., 2015). Regulations (like RBC) suggest that financial debt is subservient to claims of policyholders, combined with asymmetric information problem, insurers get to a state where financial debt becomes risky to investors.

Table 1: Trade-off theory of capital structure in insurance and other institutions

\begin{tabular}{|l|l|l|}
\hline Area of trade off & Insurance & Non-insurance \\
\hline Cost & $\begin{array}{l}\text { Capital holding cost } \\
\text { Moral hazards } \\
\text { Adverse Selection (in claim and } \\
\text { underwriting) }\end{array}$ & $\begin{array}{l}\text { Interest payment } \\
\text { Bankruptcy; default risk } \\
\text { Adverse selection (in } \\
\text { investment) }\end{array}$ \\
\hline $\begin{array}{l}\text { Agency } \\
\text { Cost/conflict }\end{array}$ & $\begin{array}{l}\text { Policyholders (customers) } \\
\text { Owners (Internal equity investors) } \\
\text { Managers }\end{array}$ & $\begin{array}{l}\text { Managers } \\
\text { Owners (shareholders) } \\
\text { Investors (Debt-investors) }\end{array}$ \\
\hline Tax & Double taxation & Not \\
\hline Benefits & $\begin{array}{l}* \text { Knows risk level to take } \\
* \text { High price charge } \\
* * * \text { Avoid financial distress }\end{array}$ & Tax shield benefits \\
\hline Capital owners & Owner-policyholder & Owner-investor \\
\hline
\end{tabular}

Source: Compiled from Cheng \& Weiss, (2012)

Recent applications of the dynamic trade off theory shows that there is a target leverage that maximizes firm value and any deviation from the target should be adjusted if value (profit and wealth) maximization is imperative (Ibrahim \& Abdul-Rahim, 2013). The authors further opined that it is only this that explicitly account for the adjustment (this connotes risk-taking) behavior. Other result shows that over levered firms moved toward target leverage quickly, probably to avoid financial distress associated with having above-target leverage (Dang, Kim \& Shin, 2012). In another result, it was shown that increase in a firm's risk is caused by a fall in the firm's equity valuation (Dierker, Kang, Lee \& Seo, 2015). In all, these outcomes are consistent with the predictions of dynamic tradeoff theory.

\subsection{The theory of risk capital and empirical application}

Theory of risk capital has been used in making argument for RBC, capital structure and performance, especially in financial firms like insurance which deal with customers and counterparties that are not prepared to bear significant default risk. The theory requires such firms to hold up sufficient equity capital to maintain an acceptable credit quality to meet their obligations and cover the financial consequences of its business risks (Erel, Myers \& Read, 2015). It is the "capital needed to keep the firm's probability of ruin below some set level" (Shimpi, 2002: 27). It is also seen as equity investment which serves as backup obligations to liability holders, including creditors, customers, and 
Sarfaraz Ahmed Bhutto et al. A conceptual review of capital structure under risk-based capital regime, risk profile of insurer's and performance

contract counterparties (Erel et al., 2015). Combining these definitions, it appears that equity is that amount required to cushion any adverse effect of financial consequences of business's risks. The important thing to note in this theory is that it specifically identifies and addresses equity as one component of capital structure that has a link with performance and business risk. Empirical findings support the theory's prediction of normal and join probability distribution of returns from marginal allocation of riskcapital (equity) (Perold, 2005). Risk capital theory buds from the trade-off theory which focuses specifically on equity as risk-related capital. The theory is used within the context of value-maximization and risk which is a dimension that enters the sequence of relational discussion of capital structure and firm performance in this study. By this theory, equity is used and must be allocated to assess profitability, and make investment decisions. Thus, it provides a clearer explanation of the relationship between equity and firm performance by linking it to profitability (returns on equity). Previous work have attempted to used this theory in explaining (though passively) the relation between capital structure and performance. In such study, it is argued that risk capital (equity) is the present value cost of acquiring complete insurance against negative returns on the firm's asset (ROA) (Merton \& Perold, 1993). The author's concluded that financial firms like insurance companies should not allocate equity back to business. They acknowledged that equity allocation is essential in evaluating risk and profitability for an existing portfolio, which is usually stable in the short run. This is another link which this theory passively mentioned business risk and performance which, as stated earlier, should be modeled into capital-performance continuum.

\subsection{The prospect theory (PT) and empirical application}

Developed in 1979 by the duo of Kahneman and Tversky as a behavioural decision theory, this theory has been used to elucidate risk-return relationship to observe firm's financial behavior (Fiegenbaum, 1990). CRP is the propensity to choose among different consequences under surroundings of probabilistic insecurity (Dan-Jumbo, 2016; Berglund, 2007). It refers to the tendency to engage in bahviours that are potentially harmful or dangerous, yet at the same time provide the opportunity for some positive outcomes (Mehdi \& Hamid, 2011). The theory suggests that top management may likely retain a poorly performing unit when the loss resulting from its performance is relatively small but will switch its preference and select risky alternatives when the performance loss becomes large and potentially ruinous (Shimizu, 2007). As the name implies, the theory posits that a decision-maker would first of all reduces each alternative in a decision problem to some series of prospects, and then evaluates each prospect according to a value (return or performance) function which centers on a set reference point. According to prospect theory, when performance is between a (normal) reference point and nearing the threat point, firms are likely to exhibits high risk profile while retaining the business line performing poorly. Once performance reaches threat point, firms will likely prefer risk-averse behavior in which case they may divest from a poorly performing business and no improvement in performance is expected. This signals the presumption that high CRP is expected to lead to increased performance. In past studies PT was found to predict a positive CRP-return relationship (Holmes et al.,

Sukkur IBA Journal of Management and Business - SIJMB | Vol 8 No. 1 January - June 2021 
Sarfaraz Ahmed Bhutto et al. A conceptual review of capital structure under risk-based capital regime, risk profile of insurer's and performance

2011). Prospect theory is use to analyses if firm's preference for higher risk result in higher performance when using the available capital or otherwise. This framework is further interpreted to mean that CRP could moderate the relationship between a firm's capital and its performance (Llopis, et al., 2013). In this study, a holistic framework for analyzing RBC is emphasized, which match these theoretical predicts but has been overlooked in empirical analysis, especially considering the differentiated and peculiar nature of insurance capital structure which is the center piece of capital related regulation like RBC. As discussed, it should be observed that in relation to different concepts explained here - namely $\mathrm{RBC}$, capital structure, risk propensity, and performance, analysis can best be performed in an integrated and interactive framework since each of this concept is not mutually exclusive.

\section{RBC Regime and Capital Structure: Insurance Perspective}

The focus of discussions and analysis in this research is on capital structure of insurance companies and not necessarily on the complexities of risk-based capital determination and effect on performance. This is because there has not been an appropriate and reliable and acceptable RBC formula, on one hand, and sufficient researchable issue on the other hand and like theory development, RBC is still in its evolutionary stage and is yet to attain a level of scientific application for prediction (Petroni, 1996). However, it is important to establish a link between the regime and firm's capital structure so as to make justifiable argument for purposes of this investigation. In this sense, regulation which is one of the three insurance-specific contexts to which the tradeoff theory has predicted a link with capital structure is discussed (Dhaene et al., 2015). Before discussing this link, it is imperative to discuss the outlook of capital structure of insurers as shown in Table 2

Table 2. Simplified balance sheet of an insurer: 'Corporate Finance Style' and 'Insurance Style'

\begin{tabular}{|l|l|l|}
\hline & \multicolumn{1}{|c|}{ Capital Structure } & \multicolumn{1}{|c|}{ Asset } \\
\cline { 2 - 3 } & \multicolumn{1}{|c|}{ Liabilities } \\
\hline $\begin{array}{l}\text { Corporate } \\
\text { Finance } \\
\text { Style }\end{array}$ & $\begin{array}{l}\text { Surplus of financial securities over technical } \\
\text { provision }\end{array}$ & \\
\hline $\begin{array}{l}\text { Insurance } \\
\text { Style }\end{array}$ & $\square$ Financial Securities & $\begin{array}{l}\text { Equity \& Technical } \\
\text { provisions }\end{array}$ \\
\hline
\end{tabular}

Source: $\quad$ Adopted from Dhaene et al., (2015)

The above structure suggests that insurers tend to use less of debt-financing and more of self-financing (Dhaene et al., 2015). From insurance perspective, the asset and liability arms of the capital structure have some sort of difference when compared with the typical corporate finance perspective of capital structure. Insurance asset is basically its financial securities without netting it over with technical provisions as it is with noninsurance firms. Similarly, insurers' liability is principally made up of equity and 
Sarfaraz Ahmed Bhutto et al. A conceptual review of capital structure under risk-based capital regime, risk profile of insurer's and performance

technical provisions while the noninsurance firms have equity and financial debt. For example, when considering the first step of the tradeoff theory, tax benefits are balanced against risk of bankruptcy and in such situation, a business plan for underwriting and investment activities in securities are balanced against such risk for insurers (Dhaene et al., 2015; Eling \& Marek, 2014). This implies that such activities together with total assets and technical provisions would all be fixed. This will reduce capital structure problems to financing of the difference between assets and technical provision and balancing of equity and technical provision, the latter is the focus of capital structure in insurance literature (Fier, McCullough, \& Carson, 2013). If asked if RBC do actually lead to significant change in insurer capital structure such that the performance of insurance firms is affected by such change, answers would vary across different respondents. However, from the statement that "...capital regulation is important in determining capital structure" we can see an answer for this investigation (Dhaene et al., 2015, p. 8). Some authors acknowledged that imposition of capital requirement actually reduced bankruptcy in US insurance industry by stopping small risky insurers from entering the market (Dhaene et al., 2015). This is so because, such risky insurers will not be able to raise sufficient fund to shore up its capital base to meet such capital requirement. Although the link between capital requirement and capital structure was found to be weak, it nonetheless, has established that there is a link. Moreover, regulations do matter especially to small insurers; low capitalized firms as it pressures them to accelerate their adjustment to target capital structure. The above discussions imply that studies involving insurance regulation, most of the times focus on capital structure. This is the reason why this study attempts to propose the framework for analyzing if capital structure under RBC would affect insurer performance given a preferred risk profile.

\section{Toward A Conceptual Framework for Capital Structure Under RBC Regime}

Based on the above discussions, a framework for capital structure integration with CRP of insurers in relation to performance under $\mathrm{RBC}$ regime is proposed in this section. The said framework will assist in conceptual understanding of issues relating to RBC from the perspective of capital structure, risk profile and performance of insurance firms. As stressed earlier, RBC regulation have significant incremental influence on a firm's capital structure just as risk profile have a role to play in capital structure to explain firm performance. Consequently, if theoretical prediction that capital and performance are positively related is to hold for insurers, there is need to integrate CRP in capital structure-performance framework. Again, as insurance capital structure differs, it will be necessary to examine if according to risk capital theory firms with fear of bankruptcy and preference for better performance would be risk takers. Increase in unpaid claims, creditors and accruals could be one way to increase capital in which case there will be sufficient funds for investment or left idle if not invested. Firms that attempts to reduce idle funds which are typically unproductive would embark on high risk investment to generate high returns. Prospect theory predict positive moderation 
Sarfaraz Ahmed Bhutto et al. A conceptual review of capital structure under risk-based capital regime, risk profile of insurer's and performance

effect of RBC on capital-performance relation (Holmes et al., 2011; Shimizu, 2007 etc). This prediction must be investigated using the right framework. Practically, whether unpaid claims, creditors and accruals can significantly alter capital structure composition and if being a risk taker can bring commensurate (high) returns is still a debate that should be investigated empirically using the right framework. Recent empirical study suggested a framework that explains the moderation effect of risk taking in the guise of corporate innovation activities (Yung-Chieh, 2016). From the precepts of PT and as explained in past studies, corporate innovation activities represent an important measure of risk-taking because it connotes an act of committing significant resource to activities with significant possibilities of failure in expectation of high returns. This implies that risk profile moderates a firm's capital structure and performance relationship. In explaining corporate innovation activities as representing risk-taking behavior, past study shows comparatively that capital allocation and R\&D investment are typically coupled with larger sum of investment...slower returns and higher risk, while the allocation of capital between R\&D and capital expenditure item reflect managers' preference to take risk (Zhou \& Huang, 2016). The authors concluded that "R\&D investment has higher risk because of its large amount of inputs, possibility of uneven distribution of benefits and high uncertainty, (p. 25)"

Empirical review further reveals two competing hypotheses on capital structure- risk relation - namely the finite risk paradigm and excessive risk paradigm. These two paradigms explain the interaction between capital structure and business risk. Whereas the finite risk paradigm states that insurers choose capital and risk level to achieve solvency risk target, the excessive risk paradigm holds that more risk taking in one area is compensated by less risk taking in another area, thus high capitalization should correlate positively with business risk. However, while the finite risk paradigm favors this positive correlation, the excessive risk paradigm explains cases where such correlation could be negative. Also, on risk and capital structure interaction, discussions have linked the effect of regulation on the decision to follow either of these paradigms. In other words, there are some empirical studies that link a firm's capital structure and its risk profile to regulations (e.g. Shim, 2010). Results from some of the studies shows that regulatory pressure positively affects changes in capital of insurers with low capitalization. Moreover, among the key financing decisions that link a firm's capital decision and performance is investment which is one of the two major activities engaged by insurance companies; the other activity being underwriting. It is contended that capital structure decision of insurers are made within the framework of enterprise risk and two categories of this risk are aligned with two principal activities namely investing and underwriting (Baranoff et al., 2007). Risk is thus an inextricable part of organizational life and is therefore, the bedrock of any successful business the world over (DanJumbo, 2016). Implicitly, these characterizations must be managed simultaneously well otherwise it may incur enormous price that can sink the firm. Hence, RBC should be discussed from the perspective of capital structure which itself should be adequately measured using equity ratio, technical provision ratio and analyze

Sukkur IBA Journal of Management and Business - SIJMB | Vol 8 No. 1 January - June 2021 
Sarfaraz Ahmed Bhutto et al. A conceptual review of capital structure under risk-based capital regime, risk profile of insurer's and performance

interactively with both quantitative and qualitative measures of CRP in relation to performance as illustrated in Fig 1 that follows:

The above framework shows a holistic view of capital structure, firm's risk profile and performance under RBC regime. The proposed framework gives insight into three basic issues that have suffered clear empirical consideration which need to be reconsidered.

- First, it shows that RBC should also be discussed within the context of capital structure. This is because RBC requirement and capital structure both are practically inextricable. The former is an activity that directly affects the later.

- Measurement of capital goes beyond one dimension or one attribute of debt ratio to include equity ratio. Particularly, for insurers, the used of debt ratio as proxy for capital structure is inappropriate, in its place technical provision ratio should be used in order to take into consideration the opportunity costs of the non-interestbearing liabilities such as unpaid claims, creditors and accruals.

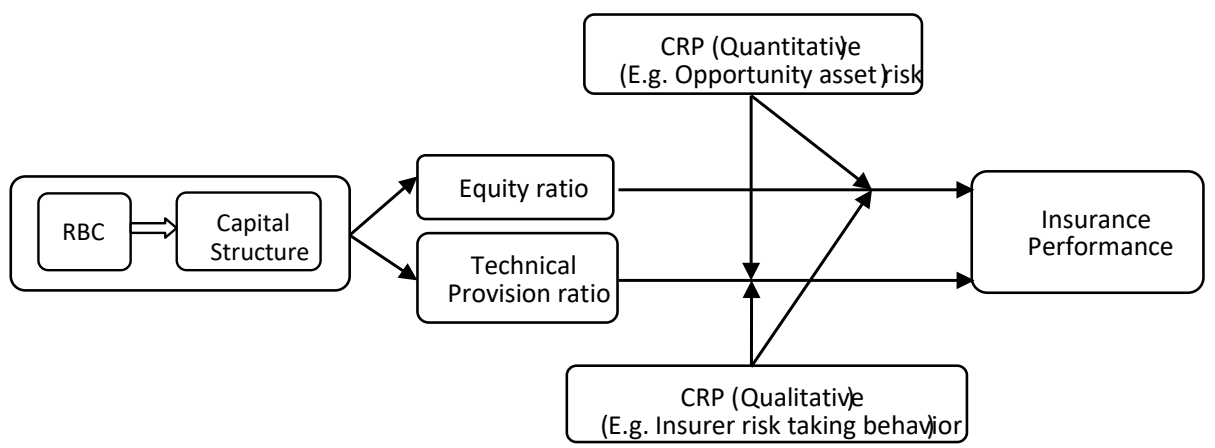

Figure 1: Conceptual framework for RBC, capital structure, risk propensity and performance

A broader understanding of the role of capital structure would require incorporating firm's level of risk it is willing to take via the deployment of the capital. Thus, high performance, by theory will imply that firms be risk takers by investing the capital risky in investment portfolios.

\section{Conclusion}

The focus of this paper was to explore how insurance firms tinker with capital structure in compliance with RBC amidst their ultimate goal of wealth and profit maximization as well as stakeholder satisfaction. Particularly it dealt with how insurers exploit the potential synergies among various internal and external sources of capital to respond to $\mathrm{RBC}$ mandates and integrate the risk components to achieve desired performance. Capital structure is basic to every firm, RBC is to strengthen capital based; risk is also an integral part of firm existence and the level assumed differs from one firm to another. In this study, we have demonstrated that under RBC regime, a firm's capital structure is affected positively and for insurance firms, different component of capital structurenamely equity, insurance fund, unpaid claims, creditors and accruals are also affected 
Sarfaraz Ahmed Bhutto et al. A conceptual review of capital structure under risk-based capital regime, risk profile of insurer's and performance

as such empirical investigation in this context is highly imperative. We have also demonstrated that such investigation should apply the right - integrated - research framework for reliable, robust and unambiguous results. It is with this that a holistic understanding of capital structure would be achieved while observed contradictions, ambiguities and inconclusive empirical findings on firm's capital structure and performance could be resolved. It is contended that with the integration of CRP, capital structure could best explain the variations in firm performance. Such framework would be important to corporate management guide them on performance improvement via capital structure, financing and corporate risk management decisions. We have explained and shown that a direct research framework of capital structure and firm performance does not provide a holistic and comprehensive analysis of capital structure effect on performance in all organizations especially insurance firm which nature of business is highly intertwined with different levels of risk propensities. Thus, for insurers, capital structure, its analysis in relation to performance will require a different measurement and different framework.

In view of the above, this paper suggested a conceptual framework emphasizing, specifically on equity ratio technical provision ratio as measures of capital structure and $\mathrm{CRP}$ as a moderating variable and performance as responsive variable within insurance discipline. The framework is typically a moderation research framework. This framework emerged following a critical review of relevant theory and empirical applications. Each theory has been discussed in this study with focus on their supporting argument on relevant path in the framework. The dynamic tradeoff theory recognizes a target level of capital and firm's adjustment behavior toward the target as a precondition for solvency. It argues that such adjustment is risk behavior. It supports the direct path between capital structure and firm performance. Theory of risk capital supports the path between RBC and capital structure. Finally, prospect theory supports the intervening role of CRP in capital structure-performance relation by arguing that a higher capital would attract higher risk taking, and a higher risk taking should result in higher returns. By prospect theory, firm performance is a function of the level of risk assumed regardless of the volume of capital acquired. It is through this framework that practitioners and academics would best explain and understands capital structure, CRP and performance under capital related regulations for insurers in particular and other firms in general.

\section{Author Contribution}

Sarfaraz Ahmed Bhutto: The main idea of research is contributed by the first author and all correspondence in the review process is being performed by him.

Ikhtiar Ali Ghumro: The visualization and setting of the conceptual model. Zulfiqar Ali Rajpe: Theoretical background and its linkage with the study. Saifullah Shaikh: Proofreading, typesetting, and flow of research paper 
Sarfaraz Ahmed Bhutto et al. A conceptual review of capital structure under risk-based capital regime, risk profile of insurer's and performance

\section{DATA AVAILABILTY STATEMENT}

This study has taken an extensive review on RBC and contributed a conceptual model. Hence, no quantitative data was used.

\section{CONFLICT OF INTEREST}

No conflict of interest

\section{FUNDING}

No external or internal funding was provided.

\section{REFERENCES}

Abdeljawad, I., Mat-Nor, F., Ibrahim, I., \& Abdul-Rahim, R. (2013). Dynamic capital structure Trade-off theory: Evidence from Malaysia. International Review of Bus. Research Papers, 9(6), 102-110.

Aghoghobvia, K. (2005). Critical Success factors for profitable management of insurance Institutions. Paper presented at the Nigerian Insurers Association Workshop in Lagos.

Baranoff, E. G., Papadopoulos, S., \& Sager, T. W. (2007). Capital and risk revisited: A structural Equation model approach for life insurers. Journal of Risk and Insurance, 74(3), 653-681

Baxter, R., Bedard, J. C., Hoitash, R., \& Yezegel, A. (2013). Enterprise risk management program Quality: determinants, value relevance, and the financial crisis. Contemporary Accounting Research, 30(4), 1264-1295

Berglund, H. (2007). Risk conception and risk management in corporate innovation: Lessons from Two Swedish cases. International Journal of Innovation Management 11(4), 497513.

Burkhanova, A., Enkov, V., Korotchenko, D., Kichkaylo, M., Marchenko, K., Rozhdestvenskaya, A. ...\& Ulugova, A. (2012). Dynamic Trade-off Theory of Capital Structure: an Overview of Recent Research. Journal of Corporate Finance Research, 3 (23), 70-86.

Cheng, J. \& Weiss, M. A. (2012). The role of RBC, hurricane exposure, bond portfolio duration, And macroeconomic and industrywide factors in property-liability insolvency prediction. The Journal of Risk and Insurance, 79 (3): 723-750.

Cheng, J. \& Weiss, M. A. (2013). Risk-based capital and firm risk taking in property-liability Insurance. The Geneva Papers on Risk and Insurance - Issues and Practice 38, 274-307.

Cheng, J., \& Weiss, M. A. (2012). Capital structure in the property-liability insurance industry: Tests of the tradeoff and pecking order theories. Journal of Insurance Issues, 1-43.

Dang, V. A., Kim, M., \& Shin, Y. (2012). Asymmetric capital structure adjustments: New Evidence from dynamic panel threshold models. Journal of Empirical Finance, 19(4), 465-482.

Dan-Jumbo T. C. (2016). Managerial perspective on risk and risk taking of quoted companies in Nigeria. Int'l Journal of Advanced Academic Research, Social \& Management Sciences, 2 (11), 57-64.

Dhaene, J., Hulle, C., Wuyts, G., Schoubben, F., \& Schoutens, W. (2015). Is the capital structure Logic of corporate finance applicable to insurers? Review and analysis. Journal of Economic Surveys, 1-21

Dierker, M. J., Kang, J. K., Lee, I., \& Seo, S. W. (2015). Risk changes and the dynamic tradeoff Theory of capital structure. business.kaist.ac.kr 
Sarfaraz Ahmed Bhutto et al. A conceptual review of capital structure under risk-based capital regime, risk profile of insurer's and performance (pp. 15-27)

Eling, M. \& Marek, S. (2014). Corporate governance and risk taking: evidence from the U.K. and German insurance markets. Journal of Risk and Insurance, 81(3), 653-682.

Erel, I., Myers, S. C., \& Read, J. A. (2015). A theory of risk capital. Journal of Financial Economics, 118(3), 620-635.

Fiegenbaum, A. (1990). Prospect theory and the risk-return association: An empirical examination In 85 industries. Journal of Economic Behavior \& Organisation, 14(2), 187203.

Fier, S. G., McCullough, K. A. \& Carson, J. M. (2013) Internal capital markets and the partial Adjustment of leverage. Journal of Banking and Finance 37(3): 1029-1039.

Florio, C., \& Leoni, G. (2017). Enterprise risk management and firm performance: The Italian Case. The British Accounting Review, 49(1), 56-74.

Gaganis, C., \& Pasiouras, F. (2013). Financial supervision regimes and bank efficiency: International evidence. Journal of Banking and Finance 37(12): 5463-5475.

Hamidah, H. (2016). Analysis of factors affecting the capital structure and profitability in Indonesian's manufacturing company year 2009 - 2013. Jurnal Keuangan Dan Perbankan, 20(2). Retrieved from http://jurnal.unmer.ac.id/jkdp/article/248

Hartman, D. G., Braithwaite, P., Butsic, R. P., et al. (1992) Property-casualty risk-based capital Requirement - A conceptual framework. The Forum Spring 1992, Casualty Actuarial Society, New York, 211-280.

Holmes, R. M., Bromiley, P., Devers, C. E., Holcomb, T. R., \& McGuire, J. B. (2011). Management theory applications of prospect theory: Accomplishments, challenges, and opportunities. Journal of Management, 37(4), 1069-1107.

Hoyt, R. E., \& Liebenberg, A. P. (2011). The value of enterprise risk management. Journal of risk And insurance, 78(4), 795-822.

Llopis, O., Garcia-Granero, A., Fernández-Mesa, A. \& Alegre, J. (2013). Managers' risk taking Propensity and innovation in organisations: The mediating influence of employees' perceived risk taking climate. 35th DRUID Celebration Conference 2013, Barcelona, Spain, June 17-19.

Matemilola, B. T., Bany-Ariffin, A. N., \& McGowan Jr, C. B. (2012). Trade off theory against Pecking order theory of capital structure in a nested model: Panel GMM Evidence from South Africa. The Global Journal of Finance and Economics, 9(2), 133-147.

Mehdi, A. A., \& Hamid, N. (2011). Entrepreneurship and risk - taking. International Conference On E-business, Management and Economics. IACSIT Press, Singapore

Merton, R. C., \& Perold. A. F. (1993). Theory of risk capital in financial firms. Journal of applied Corporate finance, 6, 16-32.

Muhlnickel, J., Weiss, G. N., \& Schmidt, A. C. (2016). Capital and the performance of insurance Companies. University of LeipzigChair of Sustainable Fin. \& Banking, Working Paper, (16-05)

Mutenga, S. \& Staikouras, S. K. (2007). The theory of catastrophic risk financing: A look at the Instrument that might transform the insurance industry. The Geneva Paper, 32, 222-245.

Perold, A. (2005). Capital allocation in financial firms. Journal of applied corporate finance, 17:110-18.

Petroni, K. R., \& Shackelford, D. A. (1996). The effect of risk-based capital on life insurers' Investment portfolios. Wharton Financial Institutions Center, University of Pennsylvania.

Shim, J. (2010). Capital-based regulation, portfolio risk and capital determination: Empirical Evidence from the US property-liability insurers. Journal of Banking \& Finance, 34(10), 2450-2461. 
Sarfaraz Ahmed Bhutto et al. A conceptual review of capital structure under risk-based capital regime, risk profile of insurer's and performance

Shim, J., \& Lee, S. H. (2016). Dependency between risks and the insurer's economic capital: A Copula-based GARCH Model. AsiaPacific Journal of Risk and Insurance. Forthcoming, doi 10.1515/apjri-2016-0021

Shimizu, K. (2007). Prospect theory, behavioral theory, and the threat-rigidity thesis: Combinative Effects on organisational decisions to divest formerly acquired units. Academy of Management Journal, 50(6), 1495-1514.

Shimpi, P. A., \& Re, S. (2002). Integrating risk management and capital management. Journal of Applied Corporate Finance, 14(4), 27-40

Shubita, M. F., \& Alsawalhah, J. M. (2012). The relationship between capital structure and Profitability. International Journal of Business and Social Science, 3(16).

Vătavu, S. (2015). The impact of capital structure on financial performance in Romanian listed Companies. Procedia Economics and Finance, 32, 1314-1322.

Yung-Chieh, C. (2013). The effects of capital structure on the corporate performance of TaiwanListed photovoltaic companies: A moderator of corporate innovation activities. Journal of Global Business Management, 9(1), 92.

Yusof, A. Y., Lau, W. \& Osman, A. F. (2015). Risk-Based Capital Framework: Conventional vs. Takaful Operators. Journal of Management Research, 7(2), 1-9 